\title{
Technetium and blood extravasation before gammagraphy: a case
} report

\author{
Sergio Vano-Galvan*1, Cristina Rodriguez-Rey², Eliseo Vano-Galvan ${ }^{3}$ and \\ Pedro Jaén ${ }^{1}$
}

\begin{abstract}
Address: ${ }^{1}$ Dermatology Service, Ramon y Cajal Hospital, University of Alcala, Madrid, Spain, ${ }^{2}$ Nuclear Medicine Service, San Carlos Hospital, Madrid, Spain and ${ }^{3}$ Radiology Service, San Carlos Hospital, Madrid, Spain

Email: Sergio Vano-Galvan* - sergiovano@yahoo.es; Cristina Rodriguez-Rey - crr24@yahoo.es; Eliseo Vano-Galvan - eliseovano@yahoo.es; Pedro Jaén - pedro@pjaen.com

* Corresponding author
\end{abstract}

Published: 22 February 2009

Cases Journal 2009, 2:141 doi:10.1186/1757-1626-2-141
Received: | 4 December 2008

Accepted: 22 February 2009

This article is available from: http://www.casesjournal.com/content/2/I//4I

(c) 2009 Vano-Galvan et al; licensee BioMed Central Ltd.

This is an Open Access article distributed under the terms of the Creative Commons Attribution License (http://creativecommons.org/licenses/by/2.0), which permits unrestricted use, distribution, and reproduction in any medium, provided the original work is properly cited.

\begin{abstract}
Background: An 80-year-old woman presented with an abrupt onset of asymptomatic black-topurple discoloration of her right limb that appeared just before a thyroid gammagraphy. No antecedent of trauma was found.

Case presentation: On questioning, patient admitted she did not cooperate during intravenous administration of Tc-99m-pertechnetate. Based on the abrupt onset of lesions and the absence of cooperation during intravenous administration of radiotracer, a suspect diagnosis of technetium and blood extravasation was made. This entity was confirmed in basis of evolution, with a spontaneous resolution of lesions within the next 15 days with no complications.
\end{abstract}

Conclusion: Patient and physicians must be reassured because of the non-vesicant property of technetium. Recovery of this entity is spontaneous, and no treatment is needed.

\section{Case presentation}

An 80-year-old woman presented with an abrupt onset of asymptomatic black-to-purple discoloration of her right limb that appeared just before a thyroid gammagraphy. No antecedent of trauma was found. Her medical history consisted on hypertension, hyperthyroidism and depression. On questioning, patient admitted she did not cooperate during intravenous administration of Tc-99mpertechnetate.

Dermatological examination showed an extensive blackto-purple soft plaque located on her distal right upper extremity, with a central depressed reddish area that coincided with peripheral intravenous access (Figure. 1). The remainder of physical examination was within normal limits. Laboratory evaluation included a complete blood cell count and a prothrombin and partial thromboplastin time, all of which were normal.

Based on the abrupt onset of lesions and the absence of cooperation during intravenous administration of radiotracer, a suspect diagnosis of technetium and blood extravasation was made. This entity was confirmed in basis of evolution, with a spontaneous resolution of lesions within the next 15 days with no complications.

\section{Discussion}

Soft tissue extravasation of radiotracer and blood after intravenous administration is a self-limited condition characterized by the appearance of a purple plaque 


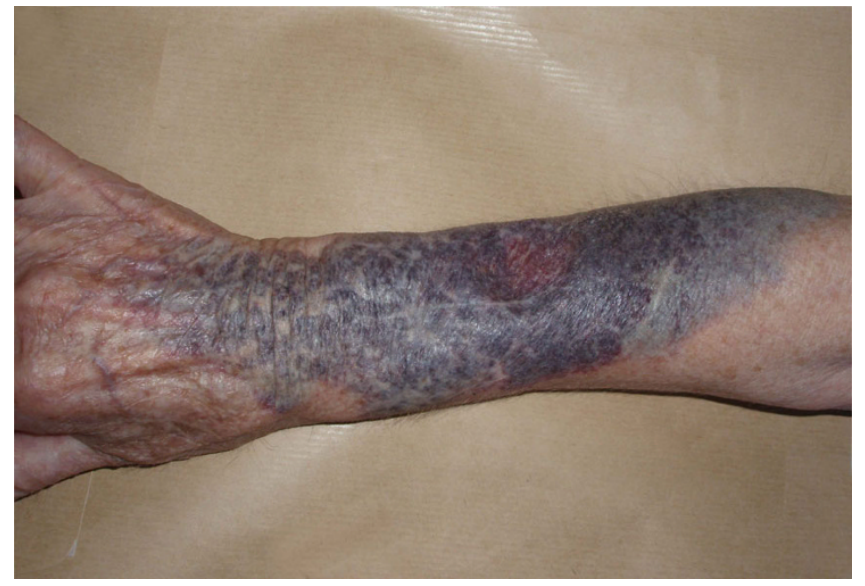

Figure I

Violaceous soft plaque located on the right arm that appeared after intravenous administration of Tc$99 \mathrm{~m}$-pertechnetate.

around the area of peripheral intravenous access. It may result in imaging artefacts [1], so nuclear imaging procedure should be repeated later on.

Recognizing radiotracer and blood extravasation is important to avoid misdiagnoses such as skin necrosis or irritant reactions like those induced by chemotherapy [2], in which the severity of tissue injury is dependent on the type and concentration of the chemotherapeutic agent and the quantity injected. Cytotoxic agents may be classified as irritants or vesicants. Irritants are drugs that can cause an inflammatory reaction, aching, swelling, pain or phlebitis at the injection site or along the vein. Vesicants are drugs that may cause severe and lasting tissue injury and necrosis. Symptoms may arise immediately after extravasation or appear after several days or weeks. In case of a significant extravasation, necrosis, eschar formation and ulceration with involvement of underlying tissues may occur [3].

Patient and physicians must be reassured because of the non-vesicant property of technetium. Recovery of this entity is spontaneous, and no treatment is needed.

\section{Consent}

Written informed consent was obtained from the patient for publication of this case report.

\section{Competing interests}

The authors declare that they have no competing interests.

\section{Authors' contributions}

SV-G wrote the initial draft of and helped revise the manuscript
CR-R and EV-G obtained consent from the patients and helped revise the manuscript

PJ assisted with manuscript revision. All authors read and approved the final manuscript

\section{References}

I. Nguyen BD: Technetium-99m MDP extravasation with cutaneous pattern of ulnar innervation. Clin Nucl Med 2004, 29:640-64I.

2. Sanborn RE, Sauer DA: Cutaneous reactions to chemotherapy: commonly seen, less described, little understood. Dermatol Clin 2008, 26:103-119.

3. Schrijvers DL: Extravasation: a dreaded complication of chemotherapy. Ann Oncol 2003, I 4 Suppl 3:iii26-iii30.
Publish with Bio Med Central and every scientist can read your work free of charge

"BioMed Central will be the most significant development for disseminating the results of biomedical research in our lifetime. " Sir Paul Nurse, Cancer Research UK

Your research papers will be:

- available free of charge to the entire biomedical community

- peer reviewed and published immediately upon acceptance

- cited in PubMed and archived on PubMed Central

- yours - you keep the copyright
BioMedcentral 